\title{
PENGEMBANGAN BROWNIES KUKUS TEPUNG TALAS- KECAMBAH KACANG HIJAU DAN UBI UNGU KUKUS (TALAHIBU) UNTUK IBU HAMIL KURANG ENERGI KRONIK
}

\author{
Development of Taro Flour-Mung Bean Sprouts and Purple Sweet Potato \\ (TALAHIBU) Steam Brownies for Pregnant Women with Chronic Energy \\ Deficiency
}

\author{
Islamiati Putri Amalia ${ }^{1}$, Hery Winarsi ${ }^{1}$, Gumintang Ratna Ramadhan ${ }^{1}$ \\ ${ }^{1}$ Jurusam Ilmu Gizi, FIKes, Universitas Jenderal Soedirman \\ Alamat korespondensi: islamiati.putriamalia6@aiesec.net
}

\begin{abstract}
Prevalence of pregnant women with a risk of Chronic Energy Deficiency (CED) is quite high (24.2\%). CED in pregnant women requires additional feeding interventions (PMT). Brownies enriched with taro flour-mung bean sprouts and purple sweet potato (TALAHIBU) was chosen as it is an energy-dense product and expected to have preferred organoleptic value and energy as PMT. Objectives of this study were to determine the phenolic antioxidant content of the best TALAHIBU formula and to determine the serving size of TALAHIBU. This factorial experimental study used a randomized block design (RBD) with 2 factors, consisting of taro flourmung bean sprout proportion and the percentage of added fine steamed sweet potato. Organoleptic variable analysis used Friedman test continued with 5\% Multiple Appeal Test. The best treatment combination was chosen, continued with Proximate and phenolic test then energy calculations. The best treatment was TALAHIBU G2J2 with water content of $23.94 \% \mathrm{BW}$; ash content $3.16 \% \mathrm{bb}$; fat $25.7 \% \mathrm{BW}$; carbohydrates $45.57 \% \mathrm{bb}$; protein $1.63 \% \mathrm{bb}$; energy $419.83 \mathrm{kcal}$; and phenolic antioxidant $19,1 \mathrm{mg} / \mathrm{g}$. It can be concluded that the best poduct TALAHIBU is suitable PMT for pregnant women with CED by serving 5 slice brownies perday. Key Word : brownies TALAHIBU, pregnant women w ith CED, Energy, Phenolic antioxidant
\end{abstract}

\begin{abstract}
ABSTRAK
Prevalensi Ibu hamil yang memiliki risiko Kurang Energi Kronis (KEK) cukup tinggi (24,2\%). KEK pada Ibu hamil membutuhkan intervensi pemberian makanan tambahan (PMT). Brownies yang diperkaya dengan tepung talas-kecambah kacang hijau dan ubi jalar ungu (TALAHIBU) dipilih karena produk ini padat energi. Brownies TALAHIBU diharapkan memiliki nilai organoleptic yang disukai, dan energi, sehingga cocok sebagai PMT. Tujuan penelitian ini untuk mengetahui kandungan antioksidan fenolik dari formula brownies kukus TALAHIBU terbaik dan mengetahui serving size TALAHIBU. Penelitian eksperimental faktorial ini menggunakan Rancangan Acak Kelompok (RAK) dengan 2 faktor terdiri dari: Proporsi tepung talas-kecambah kacang hijau dan persentase penambahan ubi jalar kukus. Analisis variabel organoleptic menggunakan Uji Friedman dan dilanjutkan dengan Uji Banding Ganda 5\%. Produk yang terbaik, dilanjutkan Uji Proksimat, uji total fenolik, dan perhitungan energi. Perlakuan terbaik adalah brownies TALAHIBU dengan proporsi tepung talas-kecambah kacang hijau 60:40 dan penambahan ubi jalar ungu 50\% (G2J2). Hasil uji proksimat brownies TALAHIBU G2J2 meliputi kandungan kadar air 23,94\%bb; kadar abu 3,16\%bb; lemak 25,7\%bb; karbohidrat 45,57\%bb; protein 1,63\%bb; energi 419,83kkal; dan total fenolik 19,1 $\mathrm{mg} / \mathrm{g}$. Brownies TALAHIBU perlakuan terbaik (G2J2) dapat dijadikan PMT untuk Ibu hamil KEK dengan serving size 5 potong brownies perhari.
\end{abstract}

Kata Kunci : brownies TALAHIBU, ibu hamil KEK, energi, antioksidan fenolik. 


\section{PENDAHULUAN}

Masa kehamilan merupakan periode yang kritis dikarenakan terjadi peningkatan kebutuhan zat gizi mikro dan makro. Oleh sebab itu asupan zat gizi pada Ibu hamil juga perlu untuk ditingkatkan untuk mencapai status gizi optimal (Kuche et al., 2015). Status gizi optimal pada ibu hamil menjadi penting karena mempengaruhi outcome kondisi kehamilan dan proses melahirkan (Pillay et al., 2016). Selain adanya perubahan peningkatan asupan, ibu hamil juga mengalami perubahan fisiologis yang merupakan bagian dari tahap mempersiapkan pertumbuhan janin dan proses kelahiran. Menurut Pillay et al. (2016), perubahan tersebut diantaranya dapat mempengaruhi kesehatan ibu hamil, salah satunya peningkatan kebutuhan ATP untuk membentuk energi dan meningkatnya risiko terpapar radikal bebas. Oleh karena itu, ibu hamil rentan terhadap masalah gizi seperti kurang energi kronis (KEK). Akibat kejadian masalah gizi tersebut, ibu hamil juga semakin rentan terpapar oleh stres oksidatif.

Menurut Grupta et al. (2010), masalah gizi dan penurunan berat badan dapat mengakibatkan menurunnya daya tahan dan kekuatan otot respirasi, ketidakseimbangan asupan makanan, stres oksidatif, dan gangguan elektrolit. Fenolik merupakan salah satu jenis antioksidan yang berfungsi mengurangi kejadian stres oksidatif dan membantu meningkatkan sediaan energi? pada ibu hamil KEK (Pillay et al., 2016).

Kekurangan energi kronis (KEK) adalah keadaan kekurangan makanan yang mengakibatkan timbulnya gangguan kesehatan ibu. Tanda dan gejalanya antara lain ukuran Lingkar Lengan Atas (LILA) < $23,5 \mathrm{~cm}$, kondisi tubuh lemah serta wajah pucat (Depkes RI, 2013). Prevalensi wanita dengan KEK adalah 15-47\% di hampir semua negara khususnya negaranegara berkembang (WHO, 2006). Hasil survey Riskedas di Indonesia pada tahun 2013 dapat diketahui bahwa prevalensi ibu hamil dengan resiko KEK sebesar 24,2\%.

Pemberian makanan tambahan (PMT) merupakan salah satu cara dalam menangani kejadian KEK dalam bentuk pemberian suplemen atau inovasi pangan. Jenis PMT yang telah beredar di masyarakat antara lain yang didistribusikan oleh Kementrian Kesehatan berupa biskuit lapis dengan isi krim strawberry (Kemenkes, 2020). Selain biscuit, PMT juga dapat dibuat dalam bentuk pangan olahan lain seperti brownies. Brownies adalah jenis cake yang berwarna cokelat kehitaman dan teksturnya tidak selembut cake pada umumnya (Astawan, 2009). Brownies 
pada umumnya memiliki bahan dasar tepung terigu dengan bahan campuran berupa telur, gula, cokelat batang dan cokelat bubuk. Menurut Haliza et al. (2012), kandungan kalori brownies talas cukup tinggi yaitu sebesar 467 kkal per 100 g brownies, sehingga dapat dijadikan variasi PMT untuk ibu hamil dengan KEK. Adanya penambahan bahan yang mengandung antioksidan pada brownies adalah salah satu upaya untuk mengurangi level stress oksidatif pada ibu hamil dengan malnutrisi seperti KEK (Pillay et al., 2016).

Talas mengandung karbohidrat yang cukup tinggi yaitu sebesar $77 \%$ (Tekle, 2009). Adanya kandungan gizi yang tinggi pada talas tersebut dapat membuka peluang agar talas untuk dibuat menjadi berbagai produk olahan seperti tepung talas. Tepung talas diperoleh dengan mengupas, mencuci, memotong umbi dengan ukuran kecil, kemudian dikeringkan dan digiling (Rosya, 2010). Tepung talas diharapkan dapat menghindari kerugian akibat tidak terserapnya umbi segar talas di pasar ketika produksi panen berlebih (Sarbini, 2015). Selain itu, tepung talas dapat dimanfaatkan sebagai bahan substitusi pada produk olahan pangan seperti brownies. Selain ubi talas, jenis ubi berupa ubi jalar ungu juga menjadi jenis ubi yang banyak berkembang di negara kita.

Selain ubi talas, jenis ubi berupa ubi jalar ungu juga menjadi jenis ubi yang banyak berkembang di negara kita. Ubi (Ipomoea batatas L.) mempunyai warna daging ungu pekat yang berasal dari kandungan antosianin (Nurdjanah et al., 2017). Kandungan antosianinnya sebesar $519 \mathrm{mg} / 100 \mathrm{~g}$ (bb) yang tergolong cukup besar, sehingga memiliki potensi untuk dijadikan sumber antioksidan (Hardoko et al., 2010). Pemanfaatannya sebagai substitusi dalam pembuatan berbagai produk cake seperti brownies. Dalam produk cake, ubi jalar ungu terlebih dahulu diolah dengan cara penepungan maupun pengukusan. Dalam penelitian ini dilakukan pengukusan ubi jalar. Menurut Ginting (2009), setelah proses pengukusan, retensi antosianin ubi jalar ungu kukus ini yaitu $64,9 \%$ yang tergolong tinggi, lebih tinggi dibandingkan proses penepungan $(12,1 \%)$.

Penggunaan talas dan ubi jalar ungu pada produk brownies belum cukup untuk memenuhi kandungan protein brownies, maka dari itu perlu ditambahkan sumber makanan tinggi protein. Bahan pangan jenis kacang merupakan sumber protein, yaitu 20-25 g/100 g bb; kacang juga memiliki kandungan vitamin $\mathrm{B}$, serat dan mineral (Dostalova, 2009). Untuk 
meningkatkan kandungan gizi pada kacang, dapat dilakukan dengan dikecambahkan. Dalam penelitian ini digunakan tepung kecambah kacang hijau sebagai sumber protein. Kacang hijau juga banyak menyumbang vitamin B1, yang berperan sebagai koenzim dalam metabolisme karbohidrat menjadi energi (Triyono et al., 2010). Penelitian ini bertujuan mendapatkan formula brownies kukus dari tepung talas-kecambah kacang hijau dan ubi jalar ungu (TALAHIBU) yang bermutu dan disukai, untuk kemudian diuji kandungan gizi dan antioksidan fenoliknya, yang memungkinkan untuk PMT ibu hamil KEK.

\section{METODE PENELITIAN}

Penelitian uji hedonik dan mutu hedonik dilakukan di lingkungan tempat tinggal peneliti yaitu di Desa Pagojengan, Kecamatan Paguyangan, Kabupaten Brebes. Uji Proksimat dan total fenolik dilakukan di Laboratorium Teknologi Pertanian Fakultas Pertanian, Universitas Jenderal Soedirman. Penelitian ini dilakukan pada bulan bulan Juli-Oktober 2020 bertepatan dengan masa pandemi COVID-19.

Pada penelitian ini, bahan-bahan diperoleh dari toko P\&D Aroma dan Intisari, Purwokerto. Bahan-bahan yang digunakan dalam penelitian ini meliputi tepung talas merk Prodes, ubi jalar ungu, kacang hijau, gula pasir, coklat bubuk merk Van Houtten, coklat blok merk Colatta, baking powder, margarine dan butter merk Palmia, telur, garam halus.

Penelitian eksperimental faktorial ini menggunakan Rancangan Acak Kelompok (RAK) dengan 2 faktor terdiri dari: Proporsi tepung talas-kecambah kacang hijau $(\mathrm{G})$ :

$$
\begin{aligned}
& \mathrm{G} 1=70: 30 \\
& \mathrm{G} 2=60: 40 \\
& \mathrm{G} 3=50: 50
\end{aligned}
$$

dan persentase penambahan ubi jalar kukus (J):

$$
\begin{aligned}
& \mathrm{J} 1=40 \% \\
& \mathrm{~J} 2=50 \%
\end{aligned}
$$

Terdapat 6 kombinasi perlakuan diulang sebanyak 4 kali sehingga diperoleh 24 unit percobaan.

a. Pembuatan Tepung Kecambah Kacang Hijau

Kacang hijau dicuci bersih, direndam dalam air 8 jam, pada suhu kamar, ditiriskan dan ditaruh pada loyang dan ditutup dengan kain selama 8-12 jam. Disiram air setiap 4 jam sekali. Kecambah kacang hijau di steamed blanching $\pm 90^{\circ} \mathrm{C} 5$ menit, lalu ditiriskan, dikeringkan dalam cabinet dryer selama 18 jam. Digiling menggunakan miller machine, 
diayak menggunakan ayakan 80 mesh (Aminah dan Hersoelistyorini, 2012).

b. Pengukusan Ubi Ungu

Ubi jalar ungu mentah, dicuci dengan air mengalir dan dibersihkan dengan sabut keras. Dipotong-potong dengan ketebalan $10 \mathrm{~mm}$. Dikukus selama 20 menit. Dihaluskan menggunakan food processor atau blender hingga halus (Selvakumaran et al., 2019).

c. Pembuatan brownies Talahibu

Telur dan gula pasir dikocok dalam wadah terpisah, menggunakan mikser kecepatan tinggi. Dimasukkan tepung talas dan tepung kecambah kacang hijau sesuai formula. Setelah margarin butter dan coklat blok dilelehkan, dimasukkan ke dalam masingmasing adonan. Dimasukkan ubi jalar ungu kukus halus ke dalam adonan, dikocok menggunakan mikser kecepatan rendah selama 5 menit. Adonan dikukus selama 25 menit. Brownies diangkat dan didinginkan pada suhu ruang.

d. Uji kadar fenolik total dengan metode kolorimetri yang mengacu pada prosedur Chun et al., (2003) Malik et al., (2015) dengan beberapa modifikasi dengan asam gallat (GAE) sebagai standar.

e. Uji hedonik dan mutu hedonik brownies TALAHIBU yaitu dilakukan pada $50+10 \%$ orang panelis tidak terlatih. Panelis mencoba sebanyak 6 formula brownies TALAHIBU dengan meminum air mineral setiap selesai mencoba masing-masing formula dan sembari mengisi kuisioner uji mutu hedonik dan uji hedonik.

\begin{abstract}
Analisis Data
Data hedonic dan mutu hedonic diuji menggunakan Friedman Test dilanjutkan dengan uji banding ganda pada taraf $5 \%$. Formula terbaik ditentukan berdasarkan uji hedonic dan mutu hedonic menggunakan Indeks Efektivitas. Produk terbaik yang didapat, dilanjutkan uji proksimat dan kandungan fenolik.
\end{abstract}

\section{HASIL DAN PEMBAHASAN}

Kombinasi proporsi tepung talaskecambah kacang hijau dengan presentase penambahan ubi jalar ungu kukus halus berpengaruh nyata pada tingkat kesukaan terhadap ?rasa, mutu rasa, aroma, dan tekstur brownies TALAHIBU $(\mathrm{P}<0,05)$. Rasa dimulai dari tanggapan rangsangan kimiawi oleh indera pengecap (lidah), hingga terjadi sifat-sifat aroma, rasa, dan 
tekstur sebagai keseluruhan rasa suatu makanan. Senyawa dapat dikenali rasanya dengan cara senyawa tersebut larut dalam air liur sehingga terjadi hubungan microvillus dan impuls yang terbentuk dikirim melalui syaraf ke pusat syarat (Winarno, 2008). Pengaruh proporsi tepung talas-kecambah kacang hijau dengan penambahan ubi jalar ungu kukus halus terhadap rasa brownies TALAHIBU menunjukkan nilai tertinggi terdapat pada proporsi tepung talas-kecambah kacang hijau 60:40 dan penambahan ubi jalar ungu $50 \%$ (G2J2) dengan nilai 4,69 yang dikategorikan suka, sedangkan nilai terendahnya terdapat pada proporsi tepung talas-kecambah kacang hijau 60:40 dan penambahan ubi jalar ungu 40\% G2J1 dengan nilai 4,02 yaitu kategori agak suka. Menurut Wijayanti (2013), cookies tepung kecambah kacang hijau memiliki rasa yang disukai. Panelis cenderung lebih menyukai formula dengan proporsi ubi jalar ungu yang lebih tinggi karena rasanya yang menjadi lebih manis.

Hasil Uji Friedman pada penelitian ini menunjukkan kombinasi proporsi tepung talas-kecambah kacang hijau dengan presentase penambahan ubi jalar ungu kukus halus (GJ) ini tidak memiliki pengaruh nyata terhadap aroma $(\mathrm{P}>0,05)$. Menurut Mervina (2012), aroma ikut menentukan penerimaan sebuah produk.
Proporsi tepung talas yang digunakan mempengaruhi aroma brownies. Terdapat sedikit bau langu pada tepung talas. Aroma langu tersebut tidak terlalu tercium, karena pada dasarnya talas bukanlah bahan makanan yang beraroma tajam. Hal tersebut sesuai dengan penelitian yang dilakukan oleh Yuliatmoko (2012), semakin tinggi kandungan tepung talas, maka aroma cookies semakin kurang disukai karena bau langu yang muncul dari tepung talas. Bau langu tersebut berasal dari oksidasi lemak, sehingga menyebabkan timbulnya hidro-peroksida saat proses pemanasan, sedangkan aroma talas pada saat perebusan; pati dalam umbi talas mengalami proses gelatinisasi sehingga rasa dan aromanya berubah dari mentah menjadi matang.

Tekstur fisik suatu makanan merupakan masalah yang berhubungan dengan gambaran panca indra (organoleptik) dari kualitas sifat raba makanan. Menurut ISO 5492, tekstur makanan adalah semua sifat mekanis, geometris, dan permukaan dari produk yang dapat dipahami melalui cara-cara mekanik, perabaan, penampakan dan suara yang ditangkap oleh reseptor. Hasil Uji Friedman pada penelitian ini menunjukkan kombinasi proporsi tepung talas-kecambah kacang hijau dengan presentase penambahan ubi jalar ungu kukus halus 
(GJ) ini tidak memiliki pengaruh nyata terhadap hedonik tekstur. Berdasarkan hasil uji hedonik, produk yang memiliki nilai tertinggi adalah G2J1 dengan nilai 4,18 (suka). Uji hedonik teksur dengan nilai terendah terdapat pada G1J2 dengan nilai 3,71 (agak suka). Hal ini sesuai dengan pendapat Mervina (2011) yang menyatakan bahwa semakin tinggi kadar protein maka semakin tinggi daya serap air dan mempengaruhi kekerasan pada brownies. Tekstur brownies yang lembut cenderung lebih disukai oleh panelis. Tekstur yang dihasilkan dari penghalusan dan pencampuran ubi jalar ungu kukus mempengaruhi hasil akhir produk brownies TALAHIBU.

Rasa adalah faktor yang paling penting dalam keputusan seorang konsumen untuk menerima atau menolak suatu makanan (Indrasti, 2004). Rasa dapat diperoleh dengan penambahan bahan tambahan seperti bumbu ataupun dari bahan baku produk, maupun dari proses pengolahan yang digunakan (Indriani, 2009). Uji Friedman pada penelitian ini menunjukkan kombinasi proporsi tepung talas-kecambah kacang hijau dengan presentase penambahan ubi jalar ungu kukus halus (GJ) berpengaruh nyata terhadap mutu rasa. Hasil analisis ragam pada mutu rasa brownies TALAHIBU menunjukkan kombinasi proporsi tepung talas-tepung kecambah kacang hijau dengan persentase penambahan ubi jalar kukus ungu halus (GJ) nilai tertinggi terdapat pada G2J2 dengan nilai 4,20 yang dikategorikan manis, sedangkan nilai terendahya terdapat pada G2J1 3,40 (agak tidak manis).

Pengujian terhadap sifat organoleptik aroma produk bertujuan untuk memperkirakan penerimaan konsumen terhadap produk (Fatima dan Masriani, 2020). Kombinasi proporsi tepung talas-kecambah kacang hijau dengan presentase penambahan ubi jalar ungu kukus halus berpengaruh nyata terhadap mutu aroma. Penilaian mutu aroma tertinggi yaitu pada G2J2 dengan penilaian 4,22 (harum), sedangkan terendahnya pada G3J2 dengan nilai 3,65 (agak harum). Hal tersebut sesuai dengan penelitian yang dilakukan oleh Yuliatmoko (2012) ketika semakin tinggi kandungan tepung talas, maka aroma cookies semakin kurang disukai karena bau langu yang muncul dari tepung talas.

Tekstur memiliki banyak arti dan penafsiran. Beberapa contoh istilah dari tekstur antara lain keras, lembut, elastis, rapuh, liat, lengket, dan licin (Diniyati, 2012). Peniliaian nilai mutu hedonik tekstur paada penelitian ini dikategorikan dengan nilai tertinggi 6 poin yang dikategorikan lembut, hingga nilai 
terendah yaitu 1, dengan 9 kategori tidak lembut. Berdasarkan hasil uji mutu hedonik, produk yang memiliki nilai tertinggi adalah brownies dengan proporsi tepung talaskecambah kacang hijau 70:30 dan presentase ubi jalar ungu 40\% (G1J1) yaitu dengan nilai 4,38 (lembut), sedangkan nilai terendah terdapat pada brownies dengan proporsi tepung talaskecambah kacang hijau 70:40 dan presentase ubi jalar ungu 50\% G1J2 dengan nilai 3,78 (agak lembut).
Penentuan formula terbaik produk terbaik ditentukan berdasarkan indeks efektivitas ditinjau dari hedonik (rasa, aroma dan tekstur) dan mutu hedonik (rasa, aroma dan tekstur) yaitu perlakuan G2J2 (perbandingan tepung talas-kecambah kacang hijau 60:40 dengan penambahan ubi jalar ungu kukus halus 50\%). Tabel 1 menampilkan kandungan gizi dan antioksidan fenolik brownies TALAHIBU terbaik.

Tabel 1. Kandungan gizi dan fenolik Brownies TALAHIBU terbaik

\begin{tabular}{lc}
\hline \multicolumn{1}{c}{ Komponen } & Kadar \\
\hline Air $(\%)$ & $23,94 \pm 0,08$ \\
Abu $(\%)$ & $3,16 \pm 0,10$ \\
Lemak $(\%)$ & $25,7 \pm 0,39$ \\
Karbohidrat $(\%)$ & $45,57 \pm 0,44$ \\
Protein $(\%)$ & $1,63 \pm 0,07$ \\
Total Fenolik $(\mathrm{mg} / \mathrm{g})$ & $1,91 \pm 1,7$ \\
\hline
\end{tabular}

Kadar air merupakan parameter yang mempunyai peranan yang besar terhadap stabilitas mutu suatu produk (Nidia, 2020). Kadar air juga dapat mempengaruhi kenampakan, tekstur, serta cita rasa makanan oleh karena itu air merupakan komponen penting dalam bahan makanan. Kandungan air dalam bahan makanan menentukan daya terima, kesegaran, dan daya tahan bahan tersebut. Jumlah kadar air dalam produk brownies akan berpengaruh terhadap tekstur maupun rasanya. Maka perlu dilakukan analisis kadar air dengan tujuan untuk mengetahui jumlah air yang terdapat pada produk brownies yang dihasilkan (Winarno, 2008). Kadar air brownies TALAHIBU sebesar 23,94\%, lebih tinggi daripada brownies hasil penelitian Wulandari et al. (2019) yaitu 20,12\%. Selain itu, untuk syarat mutu kadar air brownies menurut SNI 013840-1995 yaitu maksimal 40\%, yang berarti brownies TALAHIBU ini sudah memenuhi standar SNI. Kadar air yang lebih tinggi tersebut dikarenakan adanya penambahan ubi ungu kukus halus. Kusnandar (2010) menambahkan bahwa kadar air yang tinggi disebabkan karena 
tingginya kandungan air dari bahan baku, bentuk, ukuran, ketebalan, waktu, serta suhu pengkukusan brownies.

Kadar abu merupakan indikator adanya kandungan mineral yang terdapat di dalam suatu produk pangan. Semakin tinggi kadar abu maka kandungan mineral dalam bahan makanan tersebut semakin tinggi (Nuri et al. 2011). Kadar abu brownies TALAHIBU sebesar 3,16\%, menunjukkan angka yang lebih besar daripada temuan Wulandari et al. (2019). Namun, di sisi lain berdasarkan SNI kadar abu maksimal untuk brownies adalah $3 \%$ bb yang berarti bahwa produk terpilih tidak memenuhi SNI. Kadar abu yang tinggi pada brownies TALAHIBU terbaik, karena talas memiliki kandungan abu dan mineral yang lebih tinggi dibandingkan dengan tepung terigu (USDA, 2017). Kadar abu dalam tepung talas yaitu sebesar 0,97 g dan dalam tepung terigu lebih rendah yaitu sebesar 0,47 g. Kadar mineral yang terdapat dalam tepung talas antara lain berupa kalsium sebesar $18 \mathrm{mg}$, zat besi 0,72 mg dan magnesium sebesar 30 mg, sedangkan pada tepung terigu kalsiumnya sebesar $15 \mathrm{mg}$, zat besi sebesar 1,17 mg, dan magnesium sebesar $22 \mathrm{mg}$ (USDA, 2017).

Karbohidrat adalah sumber kalori utama bagi hampir seluruh penduduk dunia, khususnya penduduk di negara- negara berkembang. Walaupun jumlah kalori yang dihasilkan $1 \mathrm{~g}$ karbohidrat hanya 4 kkal, namun karbohidrat merupakan sumber kalori yang murah dan mudah diperoleh. Karbohidrat memiliki peranan penting dalam menentukan karakteristik bahan makanan, misalnya warna, tekstur, dan lain-lain (Indrasti, 2004). Penghitungan kadar karbohidrat dalam brownies TALAHIBU dilakukan dengan metode by difference. Jenis senyawa karbohidrat yang terukur adalah pati, gula, serat, dan oligosakarida (Indrasti, 2004). Kandungan karbohidrat formula terbaik yaitu $45,57 \%$, lebih tinggi daripada brownies penelitian Wulandari et al. (2019) yaitu $45,29 \%$. Tingginya karbohidrat pada brownies TALAHIBU berasal dari ubi jalar ungu dan tepung talas. Hal tersebut sesuai dengan pendapat Tekle (2009) bahwa talas memiliki kandungan karbohidrat yang cukup tinggi yaitu sebesar $77 \%$. Ubi jalar ungu juga menyumbang kandungan karbohidrat yaitu sebesar 58,89\% (Santosa et al., 2016), sehingga produk brownies kandungannya tinggi.

Protein merupakan unsur gizi yang sangat penting, sehingga pada hampir seluruh produk pangan jumlahnya selalu disyaratkan. Dalam sistem metabolisme, protein berfungsi sebagai unsur pembangun tubuh. Kandungan protein yang terdapat pada produk ini sebagian 
berasal dari telur, tepung talas-kecambah kacang hijau, margarin-butter, dan cokelat. Kandungan protein pada brownies TALAHIBU terpilih (G2J2) adalah 1,63\%, ternyata lebih rendah daripada brownies pada penelitian Wulandari et al. (2019) yaitu 2,96\%. Rendahnya kandungan protein dalam ubi jalar ungu kukus halus mengakibatkan protein pada brownies TALAHIBU juga rendah. Menurut SNI tahun 1992, persyaratan untuk kadar protein brownies yaitu maksimal 5,07\%bb, hal ini berarti kadar protein brownies TALAHIBU produk terpilih $(1,63 \%)$ telah memenuhi persyaratan SNI, akan tetapi apabila dibandingkan dengan syarat mutu PMT ibu hamil KEK menurut Kemenkes (2020), brownies TALAHIBU belum memenuhi batas minimal kandungan protein dalam PMT ibu hamil KEK yaitu sebesar 12g. Agar dapat memenuhi syarat PMT tersebut, maka serving size harus ditingkatkan.

Kandungan lemak brownies TALAHIBU sebesar $25,7 \%$, lebih rendah dibandingkan lemak pada brownies menurut penelitian Wulandari et al. (2019). Hasil tersebut diperkuat oleh pendapat Rodrigues et al. (2016) yang menyatakan bahwa penyerapan lemak oleh ubi jalar ungu lebih rendah dibandingkan dengan Orange Sweet Potato Puree (OSP) (38\%), dikarenakan OSP memiliki kandungan serat yang lebih tinggi dibandingkankan dengan ubi jalar ungu. Menurut SNI 013840-1995, kadar lemak untuk brownies maksimal sebesar 3\%bb. Dengan demikian kadar lemak brownies TALAHIBU belum memenuhi persyaratan SNI. Namun demikian, syarat PMT ibu hamil dengan KEK yang disampaikan oleh Kemenkes (2020) bahwa kadar lemak minimal 20\%, yang berarti kadar lemak brownies TALAHIBU telah memenuhi syarat. Dari segi kandungan lemak produk brownies TALAHIBU cocok untuk dijadikan PMT ibu hamil KEK.

Energi dalam produk makanan berasal dari nutrisi karbohidrat, protein, dan lemak. Cara penghitungan energi pada penelitian ini yaitu dengan mengonversikan setiap gram nutrisi yaitu protein dikonversikan menjadi 4 kalori, karbohidrat 4 kalori dan lemak 9 kalori (Almatsier, 2010). Hasil perhitungan energi produk brownies TALAHIBU yaitu 419,83 kkal per 100 g. Kandungan energi tersebut belum memenuhi syarat mutu Spesifikasi Teknis PMT Kemenkes (2020) yang besarnya 450 kkal per $100 \mathrm{~g}$, sehingga dari segi kandungan energi produk brownies TALAHIBU kurang memadai untuk dijadikan PMT Ibu hamil KEK. Rendahnya kandungan energi tersebut terkait dengan kandungan protein total brownies TALAHIBU yang rendah, 
sehingga brownies TALAHIBU hanya menyumbangkan sedikit energi.

Hasil total fenolik pada brownies TALAHIBU adalah sebesar 19,1 mg/g. Tepung kecambah kacang hijau kukus memiliki kandungan fenolik dan vitamin C yang baik dan dapat berfungsi antioksidan dalam tubuh (Aminah dan Wikanastri, 2012). Sumber antioksidan dalam bahan pangan terdapat pada kacang-kacangan dan serealia terutama pada kacang hijau (Winarsi et al., 2003). Menurut Jusuf et al. (2011), kandungan total fenolik pada berbagai ubi jalar ungu segar yaitu 11,20$27,79 \mathrm{mg} / \mathrm{g}$. Hingga saat ini belum ada data total fenolik berbagai ubi jalar ungu yang dikukus, namun dapat dilihat dari aktivitas antioksidannya. Fenolik merupakan salah satu jenis antioksidan yang berfungsi mengurangi kejadian stres oksidatif dan membantu meningkatkan sediaan energi pada ibu hamil KEK. Ibu hamil KEK beresiko lebih tinggi terpapar stres oksidatif karena kebutuhan ATP diubah menjadi energi lebih tinggi, daripada ibu hamil tanpa KEK (Pillay et al., 2016).

\section{Berdasarkan USDA (U.S}

Departement Agriculture), rekomendasi fenolik dari asupan untuk wanita lebih tinggi daripada pria yaitu $6 \mathrm{mg}$ per hari dan dan wanita sebesar 15,1 mg per hari (Dasgupta dan Kimberly, 2014). Oleh karena itu, total fenolik pada brownies TALAHIBU sebesar $19,1 \mathrm{mg} / \mathrm{g}$ sudah mencukupi rekomendasi asupan fenolik harian. Serving Size Berat satu potong adalah 55 g. Berdasarkan hasil perhitungan serving size, maka untuk mencukupi kebutuhan energi brownies TALAHIBU yang sesuai dengan syarat PMT ibu hamil KEK, yaitu sebanyak 5 potong brownies per hari.

\section{KESIMPULAN}

Rasa dan aroma brownies TALAHIBU yang paling disukai oleh panelis adalah produk dengan proporsi tepung talas-kecambah kacang hijau 60:40, dengan presentase penambahan ubi jalar ungu kukus halus sebanyak 50\%. Tekstur brownies yang disukai terdapat pada formula dengan proporsi tepung talaskecambah kacang hijau 50:50 dengan presentase penambahan ubi jalar ungu kukus halus $40 \%$. Mutu rasa dan aroma yang paling disukai oleh panelis adalah brownies TALAHIBU dengan proporsi tepung talas - kecambah kacang hijau 60:40, dengan presentase penambahan ubi jalar ungu kukus halus 50\%, sedangkan untuk mutu tekstur yang paling disukai adalah perlakuan dengan proporsi tepung talas - kecambah kacang hijau 60:40, dengan presentase penambahan ubi jalar ungu kukus halus 50\%. Berdasarkan 
indeks efektivitas hedonik dan mutu hedonik, formula brownies TALAHIBU terbaik adalah produk dengan proporsi tepung talas-kecambah kacang hijau 60:40, dengan presentase penambahan ubi jalar ungu kukus halus $50 \%$.

Brownies TALAHIBU mengandung air $23,94 \%$, abu 3,16\%, lemak 25,7\%, karbohidrat $45,57 \%$, protein $1,63 \%$, dan energi 419,83 kkal. Brownies TALAHIBU telah memenuhi syarat SNI, kecuali kadar abu dan lemaknya. Brownies TALAHIBU terbaik mengandung antioksidan fenolik $19,1 \mathrm{mg} / \mathrm{g}$, mencukupi rekomendasi asupan fenolik harian pada wanita. Untuk memenuhi PMT ibu hamil KEK, maka serving size brownies TALAHIBU sebanyak 5 potong brownies per hari.

\section{DAFTAR PUSTAKA}

Almatsier, S. 2010. Prinsip Dasar Ilmu Gizi. Jakarta. Gramedia Pustaka Utama.

Aminah, S., \& Wikanastri, H. 2012. Karakteristik Kimia Tepung Kecambah Serealia dan Kacangkacangan dengan Variasi Blanching. Jurnal UNIMUS Seminar Hasil-Hasil LPPM UNIMUS. Semarang.

Astawan, M., \& Khaidar, H. 2009. A-Z Ensiklopedia Gizi Pangan. Jakarta. Dian Rakyat.

Bakke, A., \& Vickers, Z. 2007. Consumer Liking of Refined and Whole Wheat Breads. Journal of Food Science 72: (473-480).
Chaudhary, R. 2004. Biochemical Assessment of Nutritional Status of Pregnant Anemic Women after a Nutritional Supplement. Asian Journal Experiment Science 18 (1): 95-112.

Dasgupta, A., \& Kimberly, K. 2014. Antioxidants in Food, Vitamins and Supplements Prevention and Treatment of Disease. Elsevier 230-231.

Depkes R.I. 1996. Pedoman Penanggulangan Ibu Hamil Kekurangan Enargi Kronis. Direktorat Pembinaan Kesehatan Masyarakat. Kemenerian Kesehatan Republik Indonesia. Jakarta.

Depkes R.I. 2002. Pedoman Penanggulangan Ibu Hamil Kekurangan Enargi Kronis. Direktorat Pembinaan Kesehatan Masyarakat. Kemenerian Kesehatan Republik Indonesia. Jakarta.

Dostalova, P. K. 2009.The Changes of Galaktosidase during Germination and High Pressure Treament of Legume Seeds. Czech Journal of Food Science 27 (Special Issue): S76-S79.

Fatima, S., \& Masriani 2017. Tingkat Kesukaan Panelis terhadap Brownies Kukus Pada Berbagai Formulasi Tepung Ampas Kelapa Borneo. Jurnal Ilmu Pertanian 3(1): 1-6.

Ginting, E. 2009. Retensi Antosianin pada Beberapa Produk Olahan Ubi Jalar. [Prosiding]: Seminar Nasional Akselerasi Inovasi Teknologi untuk Mendukung Peningkatan Produksi Aneka Kacang dan Umbi. Puslitbang Tanaman Pangan Bogor (in press). Bogor 566-569. 
Ginting, E., Jusuf, M., Rahayuningsih, S.A., Widodo, Y., Ratnaningsih., Krisnawati, A., \& Suprapto. 2006. Pemanfaatan Ubi Jalar Kaya Antosianin dan Beta Karoten. Iptek Penelitian Pangan 6(1):116138.

Ginting, E., Prasetiaswati, N., \& Widodo, Y. 2007. Penigkatan daya guna dan nilai tambah ubi jalar berukuran kecil melalui pengolahan menjadi saos dan selai. Iptek Tanaman Pangan 2 (1):110-112.

Hadinezhad, M., \& Butler, F. 2010. Effect of Flour Type and Baking Temperature on Cake Dynamic Height Profile Measurements During Baking. Journal of Food anf Bioprocess Technology (4): 594-602.

Haliza, W., Sari, I.K., \& Sri, Y. 2012. Penggunaan Mixture Response Surface Methodology pada Optimasi Formula Brownies Berbasis Tepung Talas Banten (Xanthosoma undipes K. Koch) sebagai Alternatif Pangan Sumber Serat. Jurnal Pascapanen (2): 96106.

Hardoko., Hendarto, L., \& Siregar, T. M. 2010. Pemanfaatan Ubi Jalar Ungu (Ipomoea Batatas L. Poir) Sebagai Pengganti Sebagian Tepung Terigu Dan Sumber Antioksidan Pada Roti Tawar. Jurnal Teknologi Dan Industri Pangan 21(1): 25-32.

Indriani. 2009. Butter and Sugar Cookies. Jakarta. Gramedia Pustaka Utama.

Jusuf, M., Rahayuningsih, St. A., \& Ginting, E. 2008. Ubi Jalar Ungu. Warta Penelitian dan Pengembangan Pertanian 30:1314.
Kemenkes R.I. 2020. Spesifikasi Teknis Makanan Tambahan Ibu Hamil Kurang Energi Kronis (KEK). Kementerian Kesehatan Republik Indonesia. Jakarta.

Kuche, D., Singh, P., Moges, D., \& Belachew, T. 2015. Nutritional Status and Associated Factors among Pregnant Women in Wondo Genet District, Southern Ethiopia. Journal of Food Science and Engineering 5: 85-94.

Mervina, Clara, M.K., \& Sri, A.M. 2012. Formulasi Biskuit dengan Substitusi Tepung Ikan Lele Dumbo (Clarias Gariepinus) dan Isolat Protein Kedelai (Glycine Max) sebagai Makanan Potensial untuk Anak Balita Gizi Kurang. Jurnal Teknologi dan Industri Pangan 23(1): 9-16.

Monita, F. (2016). Hubungan usia, jarak kelahiran dan kadar hemoglobin ibu hamil dengan kejadian berat bayi lahir rendah di RSUD Arifin Achmad Provinsi Riau. Jurnal Online Mahasiswa Fakultas Kedokteran Universitas Riau 2(2), 1-7.

Nidia, G. 2020. Pengaruh Substitusi Tepung Kedelai (Glycine Max (L.) Merill) terhadap Mutu Organoleptik dan Kadar Zat Gizi Makro Brownies Sebagai Alternatif Snack Bagi Anak Penderita Kurang Energi Protein. Jurnal Ilmu Gizi Indonesia 1(1):1-13.

Nurfitriani, A., \& Merry, K. 2016. Analisis Kandungan Antosianin pada Brownies Ubi Jalar Ungu. Jurnal Agrominansia 1(2): 72-80.

Oki, S., Masuda, M., Furuta, S., Nishiba, Y., Terahara, N., \& Suda, I. 2002. Involvement of anthocyanins and other phenolic compounds in 
radicalscavenging activity of purple- fleshed sweet potato cultivars. Journal of Food Science 67(5): 1752-1756.

Perdani, R.E.P., Wikanastri, H., \& Agus, S. 2018. Kadar Protein, Aktivitas Antioksidan dan Sifat Organoleptik Cookies Tersubstitusi Tepung Mocaf dan Tepung Kecambah Kacang Hijau Kukus. Jurnal Pangan dan Gizi 8(2): 11-21.

Pillay, P.S., Nelson, P.C., Heli ,T., \& Alexandre, $\quad$ M. 2016. Physiological changes in pregnancy. Cardiovascular Journal of Africa 27(2): 89-94.

Rafika, T., Nunung, N., \& Laili, H. 2012. Sifat Organoleptik Substitusi Tepumg Kimpul dalam Pembuatan Cake. Jurnal Teknologi dan Kejuruan 35( 2): 213-222.

Rampengan, V.J., \& Sembel, D.T. 1985. Dasar-dasar Pengawasan Mutu Pangan. Badan Kerjasama Perguruan Tinggi Negeri Indonesia Bagian Timur. Ujung Pandang.

Rosya. 2010. Peningkatan Kualitas Bakso Ayam dengan Penambahan Tepung Talas sebagai Subtitusi Tepung Tapioka. Jurnal Peternakan 7(2): 18-29.

Santosa, H., Handayani, N. A., Nuramelia, C., \& Sukma, N. Y. 2016. Pemanfaatan Hati Ayam sebagai Fortifikasi Zat Besi dalam Bubur Bayi Instan Berbahan Dasar Ubi Jalar Ungu (Ipomoea Batatas L). Inovasi Teknik Kimia 27-34.

Standard Nasional Indonesia (SNI). 1995. Roti. SNI 01-3840-1995. Badan Standardisasi Nasional.
Suismono. 2011. Teknologi pembuatan tepung dan pati ubi-ubian untuk menunjang ketahanan pangan. Majalah Pangan 10(37).

Sunarti 2017. Serat Pangan dalam Penanganan Sindrom Metabolik. Gadjah Mada University Pers. Yogyakarta.

Tekle, A. 2009. The Effect of Blend Proportion and Baking Condition The Quality of Cookies Made From Taro and Wheat Flour Blend. [Thesis]. Addis Ababa University. Ethiopia.

Triyono, A., Rahman, N., \& Andriana, Y. 2010. Pengaruh Proporsi Penambahan Air Pengekstraksi dan Jumlah Bahan Penstabil Terhadap Karakteristik Susu Kacang Hijau (Phaseolus radiatus L). [Prosiding]: Seminar Nasional Teknik Kimia "Kejuangan". UPN Veteran Jawa Timur 1-6.

U.S. Department of Agriculture (USDA). 2017.

Food Composition Database.

Wheat Flour, White, All Purpose, Enriched. The National Agricultural Library. United States.

Winarno, F.G. 2008. Kimia Pangan dan Gizi. Jakarta. PT. Gramedia.

Winarsi, H., Muchtadi, D. Zakaria, F. R., \& Purwantara, B. 2003. Status Antioksidan Premenapouse Yang Diberi Minuman Suplemen 'Susumeno'. [Prosiding] : Seminar PATPI Yogyakarta 2127.

World Health Organization (WHO). 2006. Adolescent Nutrition: A Review Of The Situation In Selected South-East Asian Countries WHO. New Delhi. 
J.Gipas, November 2021, Volume 5 Nomor 2 ISSN 2599-0152 eISSN 2599-2465 http://jos.unsoed.ac.id/index.php/jgps

Wulandari, Nur, A., \& Muhammad, S.S. 2019. Pengaruh Penambahan Tepung Labu Kuning (Cucurbita Moschata L) terhadap Uji Organoleptik Dan Nilai Gizi Brownies Kukus sebagai Makanan Selingan Tinggi BKaroten. Jurnal Sains dan
Teknologi Pangan 4(3): 21882203.

Yuliatmoko, W., \& Dian, I.S. 2012. Pemanfaatan Umbi Talas sebagai Bahan Subtitusi Tepung Terigu dalam Pembuatan Biskuit yang Disuplementasi dengan Kacang Hijau. Jurnal Matematika, Sains, dan Teknologi 13(2): 94-106. 